\title{
Genetic Variability among Populations of Lutzomyia (Psathyromyia) shannoni (Dyar 1929) (Diptera: Psychodidae: Phlebotominae) in Colombia
}

\section{Estrella Cárdenas ${ }^{+}$, Leonard E Munstermann*, Orlando Martínez**, Darío Corredor**, Cristina Ferro}

\author{
Laboratorio de Entomología, Instituto Nacional de Salud, Avenida Eldorado, Carrera 50, Zona Postal 6, \\ Apartado Aéreo 80080, Bogotá DC, Colombia *Department of Epidemiology and Public Health, School of \\ Medicine, Yale University, New Haven, CT, USA **Facultad de Agronomía, \\ Universidad Nacional de Colombia, Bogotá DC, Colombia
}

\begin{abstract}
Polyacrylamide gel electrophoresis was used to elucidate genetic variation at 13 isozyme loci among forest populations of Lutzomyia shannoni from three widely separated locations in Colombia: Palambi (Nariño Department), Cimitarra (Santander Department) and Chinácota (Norte de Santander Department). These samples were compared with a laboratory colony originating from the Magdalena Valley in Central Colombia. The mean heterozygosity ranged from 16 to 22\%, with 2.1 to 2.6 alleles detected per locus. Nei's genetic distances among populations were low, ranging from 0.011 to 0.049 . The estimated number of migrants $(N m=3.8)$ based on Wright's $\mathrm{F}-$ Statistic, $\mathrm{F}_{\mathrm{ST}}$, indicated low levels of gene flow among Lu. shannoni forest populations. This low level of migration indicates that the spread of stomatitis virus occurs via infected host, not by infected insect. In the colony sample of 79 individuals, the Gpi locus was homozygotic $\left({ }^{0.62} \%\right.$. 62 ) in all females and heterozygotic $\left({ }^{0.62} \% .72\right)$ in all males. Although this phenomenon is probably a consequence of colonization, it indicates that Gpi is linked to a sex determining locus.
\end{abstract}

Key words: sand flies - Lutzomyia shannoni - isozyme electrophoresis - genetic variability - dispersal gene flow Colombia

Of the more than 350 species of New World phlebotomine sand flies, only the visceral leishmaniasis vector, Lutzomyia longipalpis, has been extensively examined in terms of its population genetic structure among local populations (Morrison et al. 1995, Munstermann et al. 1998, Mutebi et al. 1998), and over a broader geographic range (Mukhopadhyay et al. 1998, Lanzaro et al. 1998, Mutebi et al. 1998, 1999). The forest sand fly $\mathrm{Lu}$. shannoni, is a zoophilic species that has an even greater geographical distribution in the Western Hemisphere, extending from the southeastern United States to northern Argentina. In Colombia, this species is widely distributed from sea level up to $1,300 \mathrm{~m}$ (Young 1979). It is a vector of vesicular stomatitis virus (VSV) (Comer et al. 1990, 1991)

\footnotetext{
This research was supported by the Colombian Instituto Nacional de Salud (Project No. 3100302 to CF of the Entomology Laboratory) and the United States National Institutes of Health (AI-34521 to LEM).

${ }^{+}$Corresponding author. Fax: +57-1-315.7341. E-mail: ecardenas95@latinmail.com

Received 27 January 2000

Accepted 4 October 2000
}

and can support the development of at least three species of Leishmania: Le. mexicana (Lawyer et al. 1987), Le. chagasi (Endris et al. 1982) and Le. panamensis (Ferro et al. unpublished). The biology of Lu. shannoni has been studied by Comer et al. (1994) and Memmott $(1991,1992)$ in field conditions and under laboratory conditions by Ferro et al. (1998) and Cárdenas et al. (1999). However, no information on population genetic structure for this phlebotomine is available. In the present study, baseline parameters of genetic variation and interpopulation migration rates were estimated and genetic diversity was compared at 13 isozyme loci among forest populations of $L u$. shannoni from three widely separated locations in Colombia and compared with a laboratory colony originating from the Magdalena Valley in Central Colombia.

\section{MATERIALS AND METHODS}

Sampling information - Sand flies were collected during day time (10 h-14 h) by aspirating them from tree trunks in a traditional coffee plantation at 1,235 m elevation near Chinácota, Department of Norte de Santander ( $7^{\circ} 34^{\prime} \mathrm{N}$, $72^{\circ} 37^{\prime} \mathrm{W}$ ); in a primary forest in Palambí at $68 \mathrm{~m}$ elevation $\left(1^{\circ} 45^{\prime} \mathrm{N}, 78^{\circ} 28^{\prime} \mathrm{W}\right)$ near the city of 
Tumaco, Department of Nariño; and in a secondary forest called San Miguel adjacent to a livestock farm at $113 \mathrm{~m}$ elevation $\left(6^{\circ} 23^{\prime} \mathrm{N}, 74^{\circ} 22^{\prime} \mathrm{W}\right)$ near Cimitarra, Department of Santander. The three sites are separated by eastern and western branches of the Andean mountain ranges, the Cordillera Oriental and Cordillera Occidental. Chinácota lies on the eastern slope, Cimitarra in the Magdalena Valley in Central Colombia, and Palambí on the Pacific Coast on the border with Ecuador (Fig. 1). After collection, the sand flies were separated by sex for visual identification, then the specimens were placed in $2 \mathrm{ml}$ cryovials, and preserved in liquid nitrogen. In addition, flies from a laboratory colony were analyzed for comparison. The colony was derived from flies collected in 1992 from secondary forests, either in Carmen de Bolívar, Bolívar Department (9 $\left.43^{\circ} \mathrm{N}, 7^{\circ} 7^{\prime} \mathrm{W}\right)$ or Magdalena Valley Puerto Boyacá, Boyacá Department $\left(5^{\circ} 58^{\prime} \mathrm{N}, 74^{\circ} 22^{\prime} \mathrm{W}\right)$ (see Results and Discussion).

Taxonomic determination - Field specimens of $L u$. shannoni were identified to the species level by morphological characteristics of the male terminalia and female spermathecae (Young \& Duncan 1994), both obtained by removing the terminal three segments of the abdomen. The remainder of the specimen was preserved in a microcentrifuge vial and frozen at $-80^{\circ} \mathrm{C}$ until used for isozyme analysis. Specimens identified as other species were preserved as voucher collections.

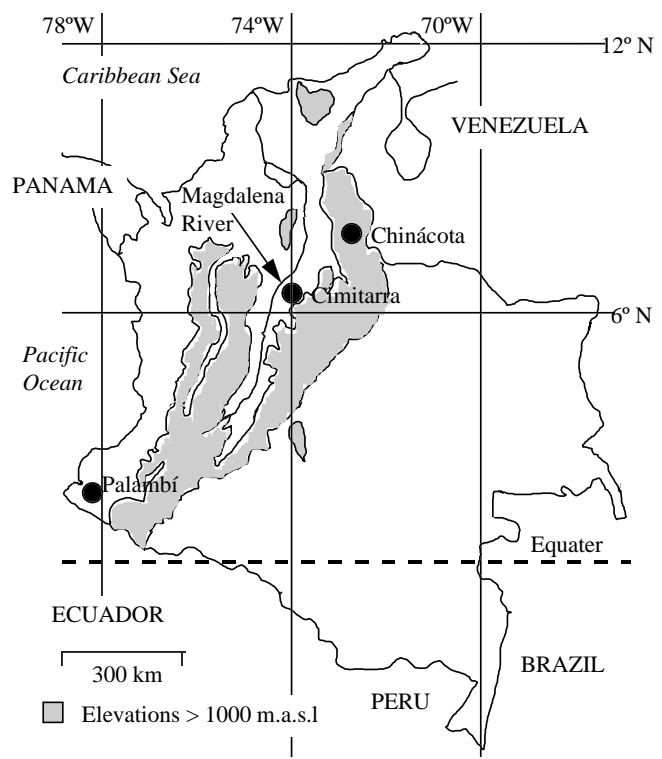

Fig. 1: sites of collection of three field Lutzomyia shannoni populations in Colombia, analyzed for genetic variability.
Electrophoretic method - Samples were analyzed for electrophoretic variation at 13 isozyme loci. Individuals of $\mathrm{Lu}$. shannoni were prepared for electrophoresis by homogenization in 10 or $20 \mu \mathrm{l}$ of grinding solution ( $10 \%$ sucrose, $0.1 \%$ Triton $\mathrm{X}-100$, $0.02 \mathrm{M}$ tris-citrate, and bromophenol blue). One to $3 \mu \mathrm{l}$ of the homogenate were applied to vertical $6 \%$ polyacrylamide gels with the volume depending on the enzyme to be assayed. Gel preparation was based on standard procedures (Munstermann 1994a). Two buffer systems $(0.025 \mathrm{M}$ tris-citrate, $\mathrm{pH} 7.0$ and $0.1 \mathrm{M}$ tris-borate-EDTA, $\mathrm{pH}$ 8.9) maximized electrophoretic separation of isozymes (Table I). Enzyme-specific histochemical staining procedures were employed to visualize isozyme phenotypes on gels (Munstermann 1994a). Samples placed on gels migrated from the cathode to the anode. The loci elucidated on a single gel were numbered sequentially from slowest to most rapidly migrating. In each locus, the allozymes were designated according to their relative mobilities $\left(R_{f}\right)$ (May 1992). The $R_{f}$ values were estimated as a ratio of distance between the origin of the gel and the leading edge of an enzyme activity zone divided by the location of the activity zone of a commercially available enzyme standard (Table I).

Data analysis - Gene and genotype data were analyzed with the BIOSYS-1 computer program (Swofford \& Selander 1981) to determine gene frequencies, genotype frequencies in equilibrium Hardy-Weinberg, average heterozygosities and genetic distances. The number of migrants among populations was based on Wright's $F_{S T}$ value and estimated by $N m=1-F_{S T} / 4 F_{S T}$ (Tabachnick \& Black 1996), where $\mathrm{Nm}=$ number of migrants every two generations and $F_{S T}$ inbreeding coefficient among populations.

\section{RESULTS AND DISCUSSION}

Genetic variability - Eleven of the 13 isozyme loci were polymorphic in all populations. The most variable locus was Est-2 with seven alleles, followed by Fum and Gpi with four alleles per locus. The following alleles showed gene frequencies $<5 \%: A k^{7.65}$ and $E s t-2^{2.00}$ in the laboratory colony; $G p i^{0.50}$ in Palambí; $I d h^{2.30}$ in Chinácota; and $A k^{5.45}, E s t-2^{1.58}, G^{0} i^{0.85}, H k^{0.83}$, and Mdh-1 $1^{1.25}$ in Cimitarra. The Ark and Est-1 loci were monomorphic in all samples. The remaining 11 loci were classified into three groups (Munstermann et al. 1998) based on mean heterozygosity $(\mathrm{H})$ : low $(\mathrm{H}=$ 0.01-0.1) Idh, Hk, Mdh-1; medium ( $\mathrm{H}=0.1-0.2) A k$, Mdh-2; and high (H>0.2) Aat, Me, Gpi, Gpd, Fum, Est-2. The laboratory colony contained seven monomorphic loci, whereas fewer were monomorphic in field samples: four in Palambi, five in Chinácota, and three in Cimitarra (Table II). 
TABLE I

Enzyme loci studied in Lutzomyia shannoni populations

\begin{tabular}{|c|c|c|c|c|}
\hline Enzyme & EC number & $\begin{array}{c}\text { Locus } \\
\text { abbreviation }\end{array}$ & $\begin{array}{c}\text { Commercial } \\
\text { reference (Sigma) }\end{array}$ & Buffer $^{a}$ \\
\hline \multicolumn{5}{|l|}{ OXIDOREDUCTASES } \\
\hline Glycerol-3-phosphate dehydrogenase & 1.1.1.8 & Gpd & G-6751 & $\mathrm{TC}$ \\
\hline Malate dehydrogenase & 1.1.1.37 & Mdh & M-9004 & $\mathrm{TC}$ \\
\hline Malic enzyme & 1.1.1.40 & $\mathrm{Me}$ & M-5257 & TBE \\
\hline Isocitrate dehydrogenase & 1.1.1.42 & Idh & I-2002 & $\mathrm{TC}$ \\
\hline \multicolumn{5}{|l|}{ TRANSFERASES } \\
\hline Aspartate aminotransferase & 2.6.1.1 & Aat & G-7005 & $\mathrm{TC}$ \\
\hline Hexokinase & 2.7.1.1 & $\mathrm{Hk}$ & $\mathrm{H}-5000$ & TBE \\
\hline Arginine kinase & 2.7.3.3 & Ark & A-3389 & $\mathrm{TC}$ \\
\hline Adenylate kinase & 2.7.4.3 & $\mathrm{Ak}$ & M-3003 & TC \\
\hline \multicolumn{5}{|l|}{ HYDROLASES } \\
\hline Esterase & 3.1.1.1 & Est & E-2884 & $\mathrm{TBE}$ \\
\hline \multicolumn{5}{|l|}{ LYASES } \\
\hline Fumarate hydratase & 4.2.1.2 & Fum & F-1757 & TBE \\
\hline Glucose phosphate isomerase & 5.3 .1 .9 & Gpi & P-5381 & TBE \\
\hline
\end{tabular}

EC: enzyme commission; $a$ : electrophoretic buffer systems: TC (0.025 M tris-citrate, $\mathrm{pH} 7.1)$; TBE $(0.1 \mathrm{M}$ trisborate-EDTA, $\mathrm{pH} 8.9$ )

In the laboratory colony, the locus $G p i$ was homozygotic in all females, whereas all males were heterozygotic (Fig. 2A). This phenomenon was never observed in field populations, although in the Palambí, Chinácota and Cimitarra samples, many more males than females were heterozygotes, (Fig. 2B). According to Bello et al. (1997), Lu. shannoni has four pairs of chromosomes with one pair heteromorphic (Jiménez et al. 2001). During the colonization of Lu. shannoni, the chromosome bearing the male sex locus apparently has trapped the 0.72 allele of $G p i$, and the chromosomes bearing the female locus became homozygous for the 0.62 allele. In 79 colony individuals examined (39 males, 40 females), no female heterozygotes were observed, indicating no crossovers and a very tight linkage between the sex locus and Gpi. One consequence of the tight linkage is a forced heterozygosity at the Gpi locus, artificially increasing the "average heterozygosity" for the colonized strain. In other diptera, entrapment of variant alleles is not uncommon in the course of laboratory colonization and inbreeding (Munstermann 1994b).

The average number of alleles per locus over all populations was 2.3 (range, 2.1-2.6). The percentage of polymorphic loci for population ranged from 38.5 to $69 \%$; the mean heterozygosity ranged from 16 to $21.7 \%$. The mean heterozygosity of the laboratory colony was very similar to the observed at Chinácota and Cimitarra, but the percentage of polymorphic loci and average number of alleles per locus were lower than in any of the wild populations (Table III).
Conformation to Hardy-Weinberg Equilibrium - Among the 52 strain-locus combinations, 19 were monomorphic. Of the remaining 33 variable loci, 16 did not conform to frequencies predicted by the Hardy-Weinberg equilibrium. Explanations for these deviations are numerous, and some or all may apply to these 16 loci. Two assumptions in applying the $\mathrm{H}-\mathrm{W}$ equilibrium are that (1) the samples were random and representative, and (2) that populations are in equilibrium. The first assumption is difficult to test (although samples were taken in from the field randomly as they were encountered) and the second is probably seldom true in a field setting. Furthermore, several of the 16 loci had common elements. The Est-2 and Fum loci were in disequilibrium in all of the four populations and therefore account for half of the 16 combinations (Table IV). These loci were also the most polymorphic and most prone to generation of large Chisquares. This was probably a function of sample size and is a frequent result in population genetic studies with highly variable loci. Attempts to resolve these cases by linkage disequilibrium analyses have been largely unsuccessful (Tabachnick \& Black 1996). $A k$ locus was in disequilibrium in Cimitarra and Palambí (monomorphic in Chinácota), and the remainder of the significantly deviant loci were distributed among populations and among loci without apparent pattern. However, all disequilibria are a consequence of heterozygote deficiency, with the exception of the Gpi deviation in the colony (Table IV). Given the direction of the disequilibrium, sampling error is an unlikely 


\section{TABLE II}

Gene frequencies at polymorphic enzyme loci for three field populations and a laboratory colony of Lutzomyia shannoni from Colombia

\begin{tabular}{|c|c|c|c|c|c|}
\hline \multirow[b]{2}{*}{ Locus } & \multirow[b]{2}{*}{$\mathrm{Rf}$} & \multicolumn{4}{|c|}{ Population } \\
\hline & & Laboratory colony & Palambí & Chinácota & Cimitarra \\
\hline \multicolumn{6}{|l|}{ Aat } \\
\hline$n$ & & 54 & 61 & 53 & 48 \\
\hline & 0.09 & 1.000 & 0.852 & 0.868 & 0.927 \\
\hline & 0.15 & $-0-$ & 0.148 & 0.132 & 0.073 \\
\hline \multicolumn{6}{|l|}{$A k$} \\
\hline$n$ & & 53 & 47 & 51 & 45 \\
\hline & 5.45 & $-0-$ & 0.053 & $-0-$ & 0.022 \\
\hline & 6.75 & 0.962 & 0.947 & 1.000 & 0.911 \\
\hline & 7.65 & 0.038 & $-0-$ & $-0-$ & 0.067 \\
\hline \multicolumn{6}{|l|}{ Ark } \\
\hline$n$ & & 53 & 47 & 51 & 45 \\
\hline & 0.94 & 1.000 & 1.000 & 1.000 & 1.000 \\
\hline \multicolumn{6}{|l|}{ Est-1 } \\
\hline$n$ & & 67 & 80 & 72 & 48 \\
\hline & 0.50 & 1.000 & 1.000 & 1.000 & 1.000 \\
\hline \multicolumn{6}{|l|}{ Est-2 } \\
\hline$n$ & & 63 & 77 & 74 & 67 \\
\hline & 1.50 & 0.167 & 0.058 & 0.068 & 0.052 \\
\hline & 1.58 & 0.278 & 0.262 & 0.101 & 0.022 \\
\hline & 1.66 & 0.167 & 0.156 & 0.182 & 0.201 \\
\hline & 1.74 & 0.111 & 0.169 & 0.277 & 0.194 \\
\hline & 1.83 & 0.151 & 0.195 & 0.182 & 0.209 \\
\hline & 1.91 & 0.087 & 0.195 & 0.128 & 0.254 \\
\hline & 2.00 & 0.040 & 0.065 & 0.061 & 0.067 \\
\hline \multicolumn{6}{|l|}{ Fum } \\
\hline$n$ & & 56 & 34 & 36 & 63 \\
\hline & 1.20 & 0.179 & 0.059 & 0.125 & 0.198 \\
\hline & 1.30 & 0.250 & 0.279 & 0.389 & 0.413 \\
\hline & 1.40 & 0.313 & 0.397 & 0.347 & 0.238 \\
\hline & 1.50 & 0.259 & 0.265 & 0.139 & 0.151 \\
\hline \multicolumn{6}{|l|}{ Gpd } \\
\hline$n$ & & 63 & 55 & 56 & 43 \\
\hline & 1.08 & 0.754 & 0.609 & 0.446 & 0.826 \\
\hline & 1.12 & 0.246 & 0.282 & 0.348 & 0.174 \\
\hline & 1.16 & $-0-$ & 0.109 & 0.205 & $-0-$ \\
\hline \multicolumn{6}{|l|}{$G p i$} \\
\hline$n$ & & 79 & 59 & 61 & 74 \\
\hline & 0.50 & -0 & 0.008 & -0 & 0.108 \\
\hline & 0.62 & 0.753 & 0.271 & 0.934 & 0.743 \\
\hline & 0.72 & 0.247 & 0.305 & 0.066 & 0.115 \\
\hline & 0.85 & $-0-$ & 0.415 & $-0-$ & 0.034 \\
\hline \multicolumn{6}{|l|}{$H k$} \\
\hline \multirow[t]{3}{*}{$n$} & & 54 & 48 & 49 & 64 \\
\hline & 0.77 & 1.000 & 0.927 & 1.000 & 0.992 \\
\hline & 0.83 & $-0-$ & 0.073 & $-0-$ & 0.008 \\
\hline \multicolumn{6}{|l|}{$I d h$} \\
\hline \multirow[t]{3}{*}{$n$} & & 54 & 46 & 50 & 40 \\
\hline & 2.00 & 1.000 & 1.000 & 0.980 & 1.000 \\
\hline & 2.30 & $-0-$ & $-0-$ & 0.020 & $-0-$ \\
\hline \multicolumn{6}{|l|}{$M d h-1$} \\
\hline \multirow[t]{3}{*}{$n$} & & 54 & 43 & 50 & 43 \\
\hline & 0.50 & 1.000 & 1.000 & 0.930 & 0.988 \\
\hline & 1.25 & $-0-$ & $-0-$ & 0.070 & 0.012 \\
\hline$M d h-2$ & & & & & \\
\hline$n$ & & 54 & 45 & 50 & 42 \\
\hline & 5.25 & 1.000 & 0.911 & 1.000 & 0.905 \\
\hline & 6.25 & $-0-$ & 0.089 & $-0-$ & 0.095 \\
\hline
\end{tabular}




\begin{tabular}{|c|c|c|c|c|c|}
\hline \multirow[b]{2}{*}{ Locus } & \multirow[b]{2}{*}{$\mathrm{Rf}$} & \multicolumn{4}{|c|}{ Population } \\
\hline & & Laboratory colony & Palambí & Chinácota & Cimitarra \\
\hline \multicolumn{6}{|l|}{$\overline{M e}$} \\
\hline \multirow[t]{4}{*}{$n$} & & 55 & 45 & 50 & 43 \\
\hline & 1.71 & 0.064 & 0.367 & 0.070 & 0.058 \\
\hline & 1.93 & 0.709 & 0.556 & 0.560 & 0.837 \\
\hline & 2.10 & 0.227 & 0.078 & 0.370 & 0.105 \\
\hline
\end{tabular}

Rf: ratio of the distance $(\mathrm{mm})$ a sample band migrates from the gel origin to the distance migrated for the same commercial enzyme (Table I); -0-: no data were observed.

A

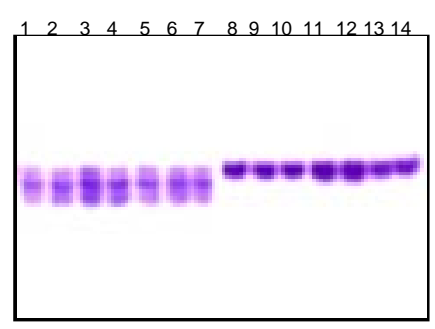

B

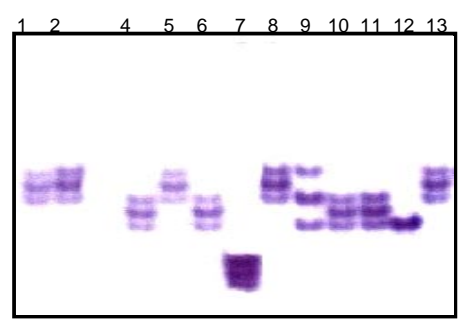

$(-)$

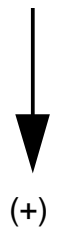

Fig. 2: electrophoretic variation of glucose phosphate isomerase in Lutzomyia shannoni. A: colony sample, lanes 1-7 males, 814 females; B: Palambí forest sample, lane 1 (colony reference), 2-5 Palambí males, lane 7 commercial Gpi, lanes 8-13 Palambí females

TABLE III

Genetic variability at 13 isozyme loci in four populations of Lutzomyia shannoni (standard errors in parentheses)

\begin{tabular}{|c|c|c|c|c|c|}
\hline \multirow[b]{2}{*}{ Population } & \multirow[b]{2}{*}{$\begin{array}{l}\text { Mean sample } \\
\text { size per locus }\end{array}$} & \multirow[b]{2}{*}{$\begin{array}{l}\text { Mean no. of } \\
\text { alleles per locus }\end{array}$} & \multirow[b]{2}{*}{$\begin{array}{c}\text { Percentage of } \\
\text { loci polymorphic }\end{array}$} & \multicolumn{2}{|c|}{ Mean heterozygosity } \\
\hline & & & & Direct-count & $\begin{array}{l}\text { Hdy-Wbg } \\
\text { expected }^{b}\end{array}$ \\
\hline $\begin{array}{l}\text { Laboratory } \\
\text { colony }\end{array}$ & $\begin{array}{l}58.4 \\
(2.1)\end{array}$ & $\begin{array}{c}2.1 \\
(0.5)\end{array}$ & 38.5 & $\begin{array}{c}0.173 \\
(0.063)\end{array}$ & $\begin{array}{c}0.219 \\
(0.084)\end{array}$ \\
\hline Palambí & $\begin{array}{l}52.8 \\
(3.7)\end{array}$ & $\begin{array}{c}2.5 \\
(0.5)\end{array}$ & 69.2 & $\begin{array}{c}0.217 \\
(0.064)\end{array}$ & $\begin{array}{c}0.305 \\
(0.086)\end{array}$ \\
\hline Chinácota & $\begin{array}{l}54.0 \\
(2.8)\end{array}$ & $\begin{array}{c}2.3 \\
(0.5)\end{array}$ & 53.8 & $\begin{array}{c}0.175 \\
(0.060)\end{array}$ & $\begin{array}{l}0.250 \\
(0.087)\end{array}$ \\
\hline Cimitarra & $\begin{array}{l}52.9 \\
(3.6)\end{array}$ & $\begin{array}{c}2.6 \\
(0.5)\end{array}$ & 61.5 & $\begin{array}{c}0.160 \\
(0.045)\end{array}$ & $\begin{array}{c}0.235 \\
(0.075)\end{array}$ \\
\hline
\end{tabular}

$a$ : a locus is considered polymorphic if the frequency of the most common allele does not exceed $0.95 ; b$ : unbiased estimate (see Nei 1978).

explanation for these occurrences, and consequently the observed heterozygote deficiencies may be due to localized inbreeding or possibly selection against heterozygous genotypes (Murphy et al. 1996). Finally, by the $p>0.05$ rejection of the null hypothesis alone, 1-2 may in fact not be in disequilibrium.

Genetic distance - Nei's genetic distances among forest populations (Palambí, Chinácota and Cimitarra) ranged between 0.023 and 0.049 , sug- gesting that the Colombian populations are genetically isolated, but still well with the range of divergence expected within a single species (see for example Tabachnick et al. 1979 for comparable distances among other haematophagus diptera). These relationships are illustrated in Fig. 3. The genetic distances are highly correlated with the geographical distances among populations: Palambí and Chinácota-0.049/950 km; Palambí and Cimitarra-0.038/680 km; Cimitarra and Chinácota- 


\section{TABLE IV}

Deviation from Hardy-Weinberg equilibrium of allozyme frequencies in Lutzomyia shannoni populations

\begin{tabular}{|c|c|c|c|c|c|c|c|}
\hline \multirow[b]{2}{*}{ Population } & \multirow[b]{2}{*}{ Loci } & \multirow[b]{2}{*}{$\chi^{2}$} & \multirow[b]{2}{*}{$\mathrm{DF}$} & \multirow[b]{2}{*}{$\mathrm{p}$} & \multicolumn{2}{|c|}{$\begin{array}{c}\text { Genotype frequencies } \\
\text { in Hardy-Weinberg } \\
\text { equilibrium? }\end{array}$} & \multirow[b]{2}{*}{ Source of disequilibrium } \\
\hline & & & & & $\mathrm{Y}$ & $\mathrm{N}$ & \\
\hline \multirow{6}{*}{$\begin{array}{l}\text { Laboratory } \\
\text { colony }\end{array}$} & $A k$ & 0.061 & 1 & 0.806 & $\mathrm{X}$ & & \\
\hline & Est-2 & 68.70 & 21 & 0.000 & & $\mathrm{X}$ & Heterozygotes deficiency \\
\hline & Fum & 84.15 & 6 & 0.000 & & $\mathrm{X}$ & Heterozygotes deficiency \\
\hline & Gpd & 3.45 & 1 & 0.063 & $\mathrm{X}$ & & \\
\hline & Gpi & 8.23 & 1 & 0.004 & & $\mathrm{X}$ & Heterozygotes excess \\
\hline & $M e$ & 5.61 & 3 & 0.132 & $\mathrm{X}$ & & \\
\hline \multirow{9}{*}{ Palambí } & Aat & 0.075 & 1 & 0.784 & $\mathrm{X}$ & & \\
\hline & $A k$ & 8.09 & 1 & 0.004 & & $\mathrm{X}$ & Heterozygotes deficiency \\
\hline & Est-2 & 78.35 & 21 & 0.000 & & $\mathrm{X}$ & Heterozygotes deficiency \\
\hline & Fum & 63.27 & 6 & 0.000 & & $\mathrm{X}$ & Heterozygotes deficiency \\
\hline & Gpd & 14.00 & 3 & 0.003 & & $\mathrm{X}$ & Heterozygotes deficiency \\
\hline & Gpi & 3.36 & 6 & 0.763 & $\mathrm{X}$ & & \\
\hline & $H k$ & 0.25 & 1 & 0.616 & $\mathrm{X}$ & & \\
\hline & $M d h-2$ & 0.37 & 1 & 0.542 & $\mathrm{X}$ & & \\
\hline & $M e$ & 70.24 & 3 & 0.000 & & $\mathrm{X}$ & Heterozygotes deficiency \\
\hline \multirow[t]{8}{*}{ Chinácota } & Aat & 1.13 & 1 & 0.288 & $\mathrm{X}$ & & \\
\hline & Est-2 & 124.22 & 21 & 0.000 & & $\mathrm{X}$ & Heterozygotes deficiency \\
\hline & Fum & 70.78 & 6 & 0.000 & & $\mathrm{X}$ & Heterozygotes deficiency \\
\hline & Gpd & 7.58 & 3 & 0.055 & $\mathrm{X}$ & & \\
\hline & Gpi & 2.88 & 1 & 0.090 & $\mathrm{X}$ & & \\
\hline & $I d h$ & 0.01 & 1 & 0.919 & $X$ & & \\
\hline & $M d h-1$ & 0.24 & 1 & 0.624 & $\mathrm{X}$ & & \\
\hline & $M e$ & 28.31 & 3 & 0.000 & & $\mathrm{X}$ & Heterozygotes deficiency \\
\hline \multirow[t]{10}{*}{ Cimitarra } & Aat & 0.252 & 1 & 0.612 & $\mathrm{X}$ & & \\
\hline & $A k$ & 28.32 & 3 & 0.000 & & $\mathrm{X}$ & Heterozygotes deficiency \\
\hline & Est-2 & 105.44 & 21 & 0.000 & & $\mathrm{X}$ & Heterozygotes deficiency \\
\hline & Fum & 89.26 & 6 & 0.000 & & $\mathrm{X}$ & Heterozygotes deficiency \\
\hline & Gpd & 0.064 & 1 & 0.800 & $\mathrm{X}$ & & \\
\hline & Gpi & 16.00 & 6 & 0.014 & & $\mathrm{X}$ & Heterozygotes deficiency \\
\hline & $H k$ & 0.00 & 1 & 1.000 & $\mathrm{X}$ & & \\
\hline & $M d h-1$ & 0.00 & 1 & 1.000 & $\mathrm{X}$ & & \\
\hline & $M d h-2$ & 0.40 & 1 & 0.526 & $X$ & & \\
\hline & $M e$ & 52.11 & 3 & 0.000 & & $\mathrm{X}$ & Heterozygotes deficiency \\
\hline
\end{tabular}

$\mathrm{Y}$ : genotype frequencies are in Hardy-Weinberg equilibrium with $\mathrm{p}>0.05$; $\mathrm{N}$ : genotype frequencies are not in Hardy-Weinberg equilibrium.

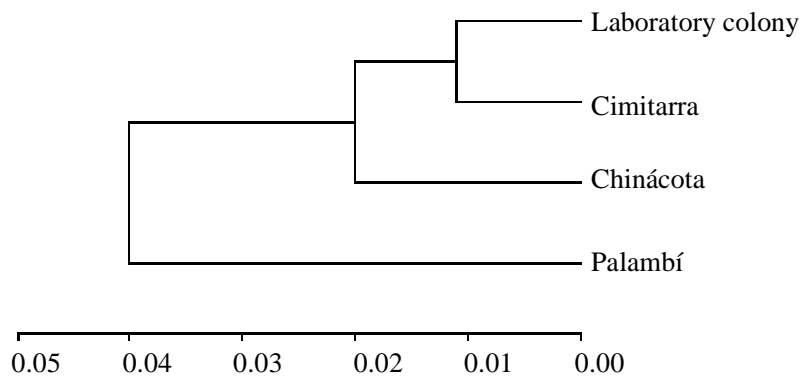

Fig. 3: genetic distance relationships (Nei 1978) among laboratory colony and field populations of Lutzomyia shannoni based on allozyme frequencies. UPGMA method was used to construct the dendrogram. 
$0.023 / 250 \mathrm{~km}$. The values obtained are similar to those obtained by Lanzaro et al. (1998) for Colombia populations of Lu. longipalpis separated by the Andean ranges. Among local populations of Lu. longipalpis, $\mathrm{Nm}$ of 17 or greater were obtained (Munstermann et al. 1998); for more distant populations separated by mountain ranges, $\mathrm{Nm}$ was 2 (Lanzaro et al. 1998). The latter results were similar to those for the $L u$. shannoni populations $(\mathrm{Nm}=3.8)$ described here, separated by 250 to 950 $\mathrm{km}$. Although "in some migration models the genetic distance is linearly related to geographical distance or area" (Nei 1972), these models are not applicable for populations separated by highly heterogeneous landscapes. Despite a correlation between the genetic distances and geographic distances measured for Colombian $\mathrm{Lu}$. shannoni, the routes of migration cannot be linear between sites - particularly in view of the weak flight capabilities of sand flies (Chaniotis et al. 1974, Morrison et al. 1993) and separation by mountain ranges exceeding 3,000 m.

$F$-statistics and gene flow - To better understand the breeding structure of local populations, the Wright statistical derivations were obtained. The laboratory colony was not included in this analysis. The inbreeding coefficient within subpopulations, $F_{I S}$, was 0.300 . An $F_{I S}>0$ indicates that the subpopulations are not in Hardy-Weinberg equilibrium, and a low value suggests reduction of heterozygosity due to inbreeding within the subpopulations (Tabachnick \& Black 1996). The inbreeding coefficient among populations $F_{S T}$, was 0.061 . The positive value suggested that gene flow was restricted among field populations. With the chi-square test, the null hypothesis was rejected at the probability level of 0.05 for the $F_{S T}$. This indicated the occurrence of gene flow among field populations, and therefore, a relatively low genetic divergence among them. The total population inbreeding coefficient, $F_{I T}$, was 0.343 . This value indicated a degree of inbreeding within subpopulations, producing a Wahlund effect among subpopulations (Tabachnick \& Black 1996).

Relevance to disease epidemiology - The migration rate estimates the dispersion potential of a pathogen transported from host to host by an insect vector. The low $\mathrm{Nm}=3.8$ (migrants every two generations) for Lu. shannoni predicts that during an epidemic outbreak of VSV, the virus is more likely to be dispersed by the vertebrate host than by the insect vector. A high potential exists for implicating $L u$. shannoni in transmission of Colombian arboviruses. Already, VSV virus (Alagoas serotype) has been isolated from $\mathrm{Lu}$. shannoni collected in the secondary forests of Arboledas and Durania, Norte de Santander Department (Tesh et al. 1987). Note that Lu. shannoni is associated almost invariably with primary and secondary forests-many of which are situated adjacent to livestock regions (Entomology Laboratory, INS). Furthermore, the Instituto Colombiano Agropecuario (ICA) has recorded large numbers of cattle infected with the New Jersey and Indiana serotypes of VSV in nearly 100 Colombian municipalities (ICA 1999). The definitive vector has not been identified, but $L u$. shannoni remains a primary suspect.

Colony origin - Although initially the colony was recorded as originating from Carmen de Bolívar, Bolívar Department, the isozyme comparisons indicated a closer relationship to the Cimitarra population. When the archival collecting records were reviewed, we found that in March 1992 sand flies were collected in two forests - one near Puerto Boyacá, Boyacá Department, and the other near Carmen de Bolívar, Bolívar Department. Since San Miguel forest in Cimitarra is closer to Los Corales forest in Puerto Boyacá $(70 \mathrm{~km})$ than Carmen the Bolívar (480 km), the laboratory colony may have been derived from Los Corales, Puerto Boyacá instead of Carmen de Bolívar. Nei's genetic distances closely group the laboratory colony with Cimitarra (Fig. 3). Since this colony is the only colonized $\mathrm{Lu}$. shannoni in the world and serves as source of insects for studies in behavior and vector competence, correct placement of its geographic origins may be relevant and may contrast significantly with populations of this species in other areas.

\section{ACKNOWLEDGMENTS}

To Marco Fidel Suarez, to personnel of the Secretaria de Salud of Norte de Santander Department, and to personnel of CIDEIN of Valle Department for their collaboration in field collections of Lutzomyia shannoni specimens.

\section{REFERENCES}

Bello FJ, Jiménez ME, Ferro C 1997. Cultivos celulares primarios de Lutzomyia shannoni (Diptera: Psychodidae) y estudio cariológico preliminar de la especie. Biomédica 17: 49-55.

Cárdenas E, Ferro C, Corredor D, Martínez O, Munstermann LE 1999. Reproductive biology of Lutzomyia shanonni (Dyar) (Diptera: Psychodidae) under experimental conditions. J Vect Ecol 24: 158170 .

Chaniotis BN, Correa MA, Tesh RB, Johnson KM 1974. Horizontal and vertical movements of phlebotomine sandflies in a Panamanian rain forest. J Med Entomol 11: 369-375.

Comer JA, Kavanaugh DM, Stallknecht, Corn JL 1994. Population dynamic of Lutzomyia shannoni (Diptera: Psychodidae) in relation to the epizootiology of vesicular stomatitis virus on Ossabaw Island, Georgia. J Med Entomol 31: 850-854.

Comer JA, Stallknecht DE, Corn JL, Nettles VF 1991. 
Lutzomyia shannoni (Diptera: Psychodidae): a biological vector of the New Jersey serotype of vesicular stomatitis virus on Ossabaw Island, Georgia. Parassitologia 33 (Suppl. 1): 151-158.

Comer JA, Tesh RB, Modi GB, Corn JL, Nettles VF 1990. Vesicular stomatitis virus, New Jersey serotype: replication in and transmission by Lutzomyia shannoni (Diptera: Psychodidae). Am J Trop Med Hyg 42: 483-490.

Endris RG, Perkins PV, Young DG, Johnson RN 1982. Techniques for laboratory rearing of sand flies (Diptera: Psychodidae). Mosquito News 42: 400- 407.

Ferro C, Cárdenas E, Corredor D, Morales A, Munstermann LE 1998. Life cycle and fecundity analysis of Lutzomyia shannoni (Dyar) (Diptera: Psychodidae). Mem Inst Oswaldo Cruz 93: 195-199.

ICA 1999. Boletín de Sanidad Animal 1996-1997. Grupo de Epidemiología Veterinaria, División de Sanidad Animal, Inst. Colomb. Agropec., Bogotá, Colombia (in press).

Jiménez ME, Bello FJ, Ferro C, Cárdenas E 2001. Brain cell karyotype of the phlebotomine sand fly Lutzomyia shannoni (Dyar) (Diptera: Psychodidae). Mem Inst Oswaldo Cruz, 96: (in press).

Lanzaro GC, Alexander B, Mutebi JP, Montoya J, Warburg A 1998. Genetic variation among natural and laboratory colony populations of Lutzomyia longipalpis (Lutz \& Neiva, 1912) (Diptera: Psychodidae) from Colombia. Mem Inst Oswaldo Cruz 93: 65-69.

Lawyer PG, Young DG, Butler JF, Akin DE 1987. Development of Leishmania mexicana in Lutzomyia diabolica and Lutzomyia shannoni (Diptera: Psychodidae). J Med Entomol 24: 347-355.

May B 1992. Starch gel electrophoresis of allozymes. In Molecular Genetic Analysis of Population. A Practical Approach, IRL, Oxford University Press, p. 1-27.

Memmott J 1991. Sandfly distribution and abundance in a tropical rain forest. Med Veterin Entomol 5: 403411.

Memmott J 1992. Patterns of sandfly distribution in tropical forest: a causal hypothesis. Med Veterin Entomol 6: 188-194.

Morrison AC, Ferro C, Morales A, Tesh RB, Wilson ML 1993. Dispersal of the sand fly Lutzomyia longipalpis (Diptera: Psychodidae) at an endemic focus of visceral leishmaniasis in Colombia. J Med Entomol 30: 427-435.

Morrison AC, Ferro C, Pardo R, Torres M, Munstermann LE 1995. An ecological and genetic study of Lutzomyia longipalpis in a central Colombian focus of visceral leishmaniasis. Bol Dir Malariol Saniamiento Ambiental 35 (Suppl. 1): 235-248.

Mukhopadhyay J, Rangel E, Ghosh K, Munstermann LE 1997. Patterns of genetic variability in colonized strains of Lutzomyia longipalpis (Diptera: Psychodidae) and its consequences. Am J Trop Med Hyg 57: 216-221.

Mukhopadhyay J, Ghosh K, Rangel E, Munstermann LE 1998. Genetic variability in biochemical charac- ters of Brazilian field populations of the Leishmania vector, Lutzomyia longipalpis (Diptera: Psychodidae). Am J Trop Med Hyg 59: 893-901.

Munstermann LE 1994a. Electrophoresis Procedures, Sand Fly Genetics Program, Yale School of Medicine, New Haven, Connecticut, $31 \mathrm{pp}$.

Munstermann LE 1994b. Unexpected genetic consequences of colonization and inbreeding: allozyme tracking in Culicidae (Diptera). Ann Entomol Soc Am 87: 157-164.

Munstermann LE, Ferro C, Pardo R, Torres M, Morrison AM 1998. Genetic structure of local populations of Lutzomyia longipalpis (Diptera: Psychodidae) in Central Colombia. J Med Entomol 35: 82-89.

Murphy RW, Sites JW, Buth D Jr, Haufler CH 1996. Proteins: isozyme electroforesis. In DM Hills, C Moritz, BK Mable (eds), Molecular Systematics, Sinauer Associates, Inc., Sunderland, Massachusetts, $655 \mathrm{pp}$.

Mutebi JP, Alexander B, Sherlock I, Wellington J, Souza AA, Shaw J, Rangel EF, Lanzaro GC 1999. Breeding structure of the sand fly Lutzomyia longipalpis (Lutz \& Neiva) in Brazil. Am J Trop Med Hyg 61: 149-157.

Mutebi JP, Rowton E, Herrero MV, Ponce C, Belli A, Valle S, Lanzaro GC 1998. Genetic variability among populations of the sand fly Lutzomyia (Lutzomyia) longipalpis (Diptera: Psychodidae) from Central America. J Med Entomol 35: 169-174.

Nei M 1972. Genetics distance between populations. Am Nat 106: 283-291.

Nei M 1978. Estimation of average heterozygosity and genetic distance from a small number of individuals. Genetics 89: 583-590.

Swofford DL, Selander RB 1981. BIOSYS-1: a FORTRAN program for the comprehensive analysis of electrophoretic data in population genetics and systematic. J Hered 72: 281-283.

Tabachnick WJ, Black IV WC 1996. Population genetics in vector biology. In BJ Beaty, WC Marquardt (eds), The Biology of Disease Vectors, University Press of Colorado, Niwot, Colorado, $632 \mathrm{pp}$.

Tabachnick WJ, Munstermann LE, Powell JR 1979. Genetic distinctness of sympatric forms of Aedes aegypti in East Africa. Evolution 33: 287-295.

Tesh RB, Boshell J, Modi GB, Morales A, Young DG, Corredor A, Ferro C, Rodriguez C, Walters L, Gaitán MO 1987. Natural infection of humans, animals, and phlebotomine sandflies with the Alagoas serotype of vesicular stomatitis virus in Colombia. Am J Trop Med Hyg 36: 653-661.

Young DG 1979. A Review of the Bloodsucking Psychodid Flies of Colombia (Diptera: Phlebotominae and Sycoracinae), Tech. Bull. 806, Agric. Exp. Station, IFAS, Univ. Florida, Gainesville, 226 pp.

Young DG, Duncan MA 1994. Guide to the Identification and Geographic Distribution of Lutzomyia Sand Flies in Mexico, the West Indies, Central and South America (Diptera: Psychodidae), Am Entomol Inst, Gainesville, Florida, 881 pp. 